\title{
Mikrofabrikasi Jalur PCB Menggunakan Metode Visible Ligth Maskless Photolitography
}

\author{
Dedi Suwandi ${ }^{1}$, Badruzzaman $^{2}$, Jos Istiyanto ${ }^{3}$ \\ 1,2 Jurusan Teknik Mesin \\ Politeknik Negeri Indramayu \\ ${ }^{3}$ Fakultas Teknik Jurusan Teknik Mesin \\ Universitas Indonesia \\ E-mail : dedi@polindra.ac.id ${ }^{1}$, bagus_200409@yahoo.com², josist@eng.iu.ac.id ${ }^{3}$
}

\begin{abstract}
Abstrak
Pada tulisan ini akan dibahas metode modifikasi dari Photolitography yaitu Visible Ligth Maskless Photolitography, perbedaannya menggunakan sinar tampak (visible light) dan tanpa mask (cetakan) selanjutnya diaplikasikan pada fabrikasi jalur listrik $P C B$ (printed circuit board). Modifikasi metode ini dilakukan karena metode yang sudah ada membutuhkan alat dan mesin yang mahal kemudian dirancang untuk produksi masal. Padahal dibutuhkan juga metode yang tepat untuk membuat jalur listrik $P C B$ sendiri dengan jumlah satuan. Untuk menjawab persoalan tadi maka dibuat sebuah metode dengan kelebihan mudah dalam proses pembuatan, peralatan lebih murah dibandingkan mesin industri tetapi mampu membuat profil jalur $P C B$ yang rapih dan rumit kemudian aman untuk lingkungan. Cara kerjanya model/ profil dibuat di komputer/ laptop kemudian dipancarkan melalui $D L P$ projector. Pada bagian bawah projector dipasang $P C B$ yang sudah dilapisi Negative Photoresist sehingga terjadi proses exposure. Selanjutnya dilakukan proses developing dan eching sehingga terbentuk profil sesuai desain. Pada jenis projector Infocus IN114A ditemukan parameter terbaik: posisi lensa pemfokus pembesaran $3 \mathrm{X}$ berjarak $3 \mathrm{~cm}$ di bawah DLP projektor dan $14 \mathrm{~cm}$ di atas material uji $P C B$, menggunakan kombinasi warna hitam (R:0 G:0 B:0) dan biru terang ( $R=0, G=176, B=240$ ) dengan waktu prebake 2 menit, spin $2.000 \mathrm{rpm}$, exposure 3 menit, developing 5 menit, Postbake 5 menit dan Eching 5 menit. Profil jalur $P C B$ yang berhasil dibuat di antaranya: garis, huruf, alur listrik, dan bentuk microcontroller. Hasil pengukuran Scanning Electron Microscope (SEM) profil garis terkecil yang dapat dibuat yaitu $\mu \mathrm{m} 132 \mu \mathrm{m}$ dan memiliki kekasaran tepi (deviasi) 6,6 $\mu \mathrm{m}$.
\end{abstract}

Kata Kunci: Mikrofabrikasi PCB, Maskless Photholithography, Visible Ligth Maskless Photolitography.

\section{PENDAHULUAN}

$P C B$ (printed circuit board) merupakan tempat menaruh rangkaian komponen listrik tanpa kabel, dalam perkembangannya papan ini sangat membantu revolusi bentuk alat elektronik dari segi desain dan ukuran. Proses fabrikasi papan $P C B$ terus mengalami perbaikan, selain mengembangkan metode yang sudah ada, dilakukan juga pencarian metode baru untuk meningkatkan kualitas produk, waktu pengerjaan dan biaya produksi.

Selama ini terdapat beberapa cara membuat profil di $P C B$ mulai dari cara manual yang menggunakan alat sederhana yang ada disekitar kita hingga menggunakan mesin-mesin canggih dan otomatis untuk skala produksi. Semua cara tadi memiliki kelebihan dan kekurangan di antaranya: Proses manual (menggambar dengan spidol langsung di $P C B$ dilanjutkan dengan proses eching), kelebihannya mudah dan murah, kekurangannya profil yang mampu dibuat sangat sederhana dengan ukuran besar dan kasar kemudian tidak mampu menghasilkan jalur dengan kualitas sama; Pemindahan cetakan (menggunakan printer dan strika), kelebihannya mampu membuat profil lebih rumit dari metode manual, kekurangannya hasil profil kasar dan kualitas profil tidak sama; $P C B$ laserprinter (mengikis $P C B$ dengan sinar laser) (Triano, A, 2013:1), (Aos Alwaidh, 2014:109), kelebihannya mampu menghasilkan profil rumit dan halus, kekurangannya waktu pengerjaan lama, mesin dan alat yang digunakan mahal kemudian menggunakan sinar laser yang berbahaya; $P C B$ miling (mengikis secara mekanis) (Arturo Moreno, 2012:240), kekebihannya mampu membuat profil rumit, kekurangannya hasil profil kasar, waktu pengerjaan lama, alat dan mesin mahal kemudian pahat/tool gampang patah dan susah diperbaiki; lithography (menggunakan sinar dan cairan photoresist), metode ini yang banyak digunakan diindustri.

Proses lithography sendiri memiliki beberapa metode yang dibedakan berdasarkan penggunaan sinar sumber prosesnya, diantaranya: UV lithography (Y. Hirai, 2007: 545) (A. Bertsch, 1998:14), yang menggunakan sinar Ultra Violet metode ini mampu menghasilkkan profil berskala mikro dan X-Ray lithography (S.M.P. Kalaiselvi, 2014:1) (W. Ehrfeld, 1998:81) yang menggunakan sinar $X$-ray yang mampu menghasilkan profil berskala nano. Kedua metode lithography ini yang banyak digunakan di industri semikonduktor walaupun memiliki kekurangan dari segi alat dan mesin yang mahal 
serta bahaya karena menggunakan sumber sinar yang tidak aman. Bagi pihak industri kekurangan tadi dapat ditutupi oleh jumlah dan waktu pengerjaan yang dibutuhkan sangat singkat dengan kualitas yang sama.

Dari beberapa metode yang sudah ada tadi masih terdapat masalah yang perlu diselesaikan dalam pembuatan jalur $P C B$, yaitu tidak ada metode yang mampu membuat jalur yang rumit kemudian menghasilkan profil yang halus dan dengan biaya yang murah serta aman.

Dengan keterbatasan tersebut maka dicarilah metode baru oleh peneliti (Dhanesh K.R dkk, 2013:194) mengganti sumber sinar yang umumnya menggunakan sinar UV atau sinar X-Ray diganti dengan sinar tampak yang berasal dari DLP (Digital Micromirror Device) projector dan tanpa cetakan (maskless). Tetapi penelitian tersebut belum berhasil diaplikasikan karena terdapat masalah pada saat penyinaran yaitu sinar putih yang digunakan tidak dapat difokuskan sehingga bentuk yang diinginkan tidak dapat dimunculkan.

Selanjutnya akan dilakukan perbaikan proses fabrikasi jalur listrik pada $P C B$ dengan metode yang hampir sama yaitu menggunakan sinar tampak (visiblelight), kemudian tanpa menggunakan cetakan (maskless) karena sumber sinar yang digunakan berasal dari DLP projector sehingga metode ini disebut visible light maskless photolithography. Perbedaan metode ini pada pencarian kombinasi warna terbaik exposure yang dikeluarkan DLP projector, yang tidak dilakukan pada penelitian sebelumnya yaitu hanya menggunakan kombinasi warna hitam dan putih saja. Prinsip kerjanya $P C B$ yang sudah diproses lithography akan di kikis (eching) menggunakan cairan Ferri Chloride $\left(\mathrm{FeCl}_{3}\right)$. Tujuannya adalah mencari parameter terbaik proses visible light maskless photolithography.

Harapannya adalah menemukan metode modifikasi photolithography pembuatan jalur listrik pada $P C B$ dengan kelebihan mudah dalam pembuatannya karena peralatan untuk metode ini mudah ditemukan seperti Laptop/ PC, DLP projector, kaca pembesar, cairan photoresist dan ferric chloride. Kemudian mampu membuat jalur $P C B$ yang rumit dengan memiliki variasi bentuk garis, ukuran garis yang mampu membuat dalam skala ratusan mikron sehingga lebih rapih dibandingkan dengan cara manual menggunakan spidol atau pemindahan cetakan (printer dan strika). Selanjutnya dengan metode ini dapat menekan biaya, karena jika membuat desain jalur $P C B$ sendiri ke industri maka ada batasan jumlah pesanan padahal kita hanya butuh satu atau dua buah saja. Harapan selanjutnya dengan metode ini lebih aman karena sinar sumber exposure yang digunakan adalah sinar tampak bukan sinar $U V$ atau $X$ Ray (dibawah $400 \mathrm{~nm}$ ) seperti di industri yang membahayakan manusia dan lingkungan.

\section{METODE}

Photo-litho-graphy, menurut bahasa latin berarti cahaya-batu-tulisan, sedangkan pengertiannya adalah proses mikrofabrikasi yang memindahkan bentuk geometris dari mask (pola cetakan) ke permukaan substrate (landasan) yang biasanya berupa silicon, silicon dioxide, aluminum oxide, copper dan lain-lain (Wolfwikis, 2015). Proses pemindahan umumnya menggunakan sinar $U V$ yang dipancarkan kearah mask (cetakan), sinar yang tertahan oleh mask tidak akan diteruskan, sedangkan sinar yang tidak tertahan pola mask akan diteruskan mengenai substrate yang sudah dilapisi cairan photoresist (negative/positive). Cairan photoresist, pada bagian yang terkena sinar dengan yang tidak terkena sinar akan bereaksi berbeda sesuai jenisnya. Perbedaan reaksi pada cairan photoresist yaitu satu bagian akan mengeras dan yang satu bagian lagi tidak mengeras masih berbentuk cair sehingga dapat dihilangkan pada saat proses develop (pelarutan resist). Bagian yang mengeras akan melindungi substrate sehingga tidak terkikis pada saat dilakukan proses eching. Contoh aplikasi produk yang menggunakan proses ini seperti IC (integrated circuits) dan CMOS (Complementary metal-oxide-semiconductor). Langkahlangkah dalam proses Photolithography (Sigmaaldrich , 2015) meliputi:

\section{- Substrate preparation}

Proses ini bertujuan untuk membersihkan substrate dari debu, partikel abrasive, benang/kertas penyeka, photoresist residu bakteri, minyak dan benda lain. Setelah wafer/ substrate dipotong kemudian direndam pada cairan acetone, methanol, De-Ionized water (DI $\mathrm{H}_{2} \mathrm{O}$ ) selama 2-5 menit dan dikeringkan menggunakan uap udara kering atau dari hairdryer $120-200^{\circ} \mathrm{C}$.

- Photoresist spin coating

Proses ini bertujuan untuk meratakan cairan photoresist pada permukaan substrate dengan cara diputar pada 2000-5000 rpm untuk bentuk lingkaran dan 500-1000 rpm untuk bentuk persegi.

- Pre-Bake (Soft Bake)

Bertujuan untuk menguapkan cairan pembersih dengan cara dipanaskan pada hotplate bersuhu $82^{\circ} \mathrm{C}$ selama 20 menit pada oven bersuhu $90-100^{\circ} \mathrm{C}$ selama 20 menit.

- Alignment and Exposure

Bertujuan untuk memindahkan pola dari mask ke substrate ada 3 jenis metode yang digunakan contact, proximity dan projection: Perbedaannya ada jarak (gap) pada metode proximity dan menggunakan 2 lensa pada metode projection seperti pada gambar 1 . Waktu exposure sekitar 1-10 detik dengan intensitas cahaya $100 \mathrm{~mW} / \mathrm{cm}^{2}$.

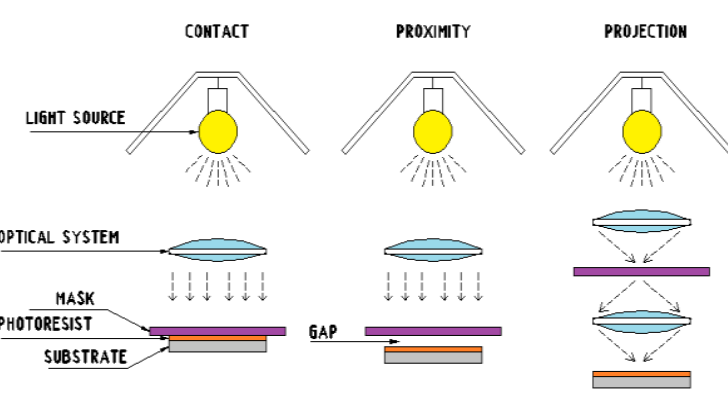

Gambar 1. Metoda exposure 


\section{- Development}

Proses ini bertujuan mengangkat profil photoresist yang tidak diinginkan, menggunakan cairan developer. Proses ini dilakukan selama 1-60 detik.

- Post-Bake (Hard Bake)

Proses ini dilakukan untuk mengeraskan photoresist yang sudah di develope. Waktu yang diperlukan 1020 menit pada $120^{\circ} \mathrm{C}$.

Cairan photoresist adalah bahan yang mudah bereaksi jika terkena cahaya. Dengan sifat inilah cairan photoresist dipilih dalam proses photolithography. Ada dua jenis cairan photoresist yaitu Positive dan Negative. Positive photoresist akan tertinggal di substrate jika tidak tersinari dan akan hilang (terdevelope) jika tersinari, sebaliknya Negative photoresist akan tertinggal di substrate jika tersinari dan akan terdevelope pada bagian yang tidak tersinari. Sinar yang digunakan biasanya $U V$ atau X-Ray yang dipancarkan melewati cetakan (mask) yang memiliki pola sehingga bayangan pola akan terbentuk pada cairan photoresist diatas substrate. Perbedaan reaksi jenis resist dapat dilihat pada gambar 2.

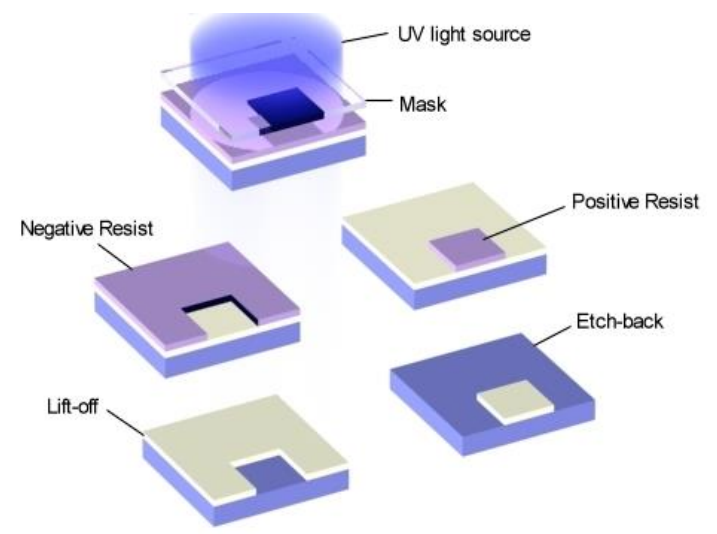

Gambar 2. Perbedaan positive dan negative resist [9].

Maskless Photolithography adalah salah satu modifikasi dari Photolithography umum, metode ini tidak menggunakan cetakan (mask). Dengan tidak dibuatkan cetakan (mask) menambah kemudahan proses ini, karena pada metode Photolithography umum biasanya ada proses pembuatan masking dengan mesin yang sangat rumit dan mahal selanjutnya satu cetakan hanya untuk satu benda. Cetakan (mask) digantikan dengan sumber sinar dari DLP (Digital Micromirror Device) projector yang mampu menghasilkan warna hitam yang berfungsi menggantikan cetakan (mask) dengan bentuk dan ukuran yang dapat dirubah sesuai keinginan. Pada metode Photolithography umum biasanya cahaya yang digunakan adalah Ultra Violet atau X-Ray yang berbahaya untuk lingkungan dan manusia. Dengan menggunakan sumber cahaya dari DLP Projector maka sinar yang keluar lebih aman.

Cara kerja proses Maskless Photolithography yaitu membentuk profil atau model dibuat di laptop atau komputer, kemudian laptop tadi dihubungkan dengan DLP projector untuk menyinarkan profil yang sudah dibuat dari laptop. Sinar yang keluar dari projector akan diatur menggunakan kaca pemfokus supaya tepat mengenai cairan resist yang sudah dioleskan diatas landasan (substrate). Posisi projector dapat diatur dengan pergerakan 3 sumbu untuk menentukan jarak dan titik fokus penyinaran (exposure), seperti pada gambar 3 .

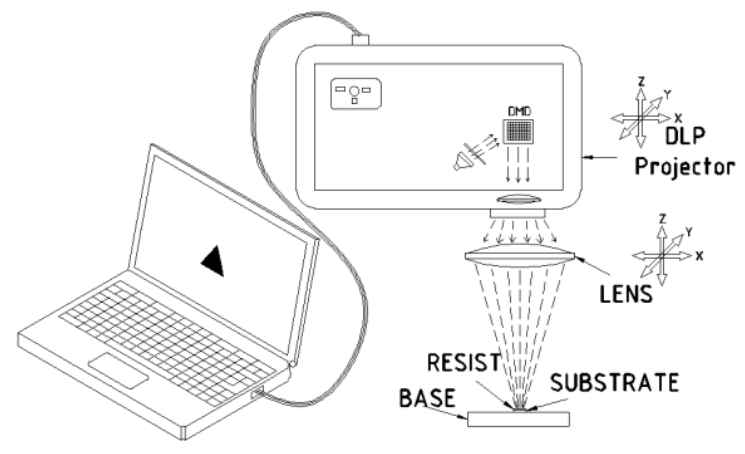

Gambar 3. Skema Maskless Photolithography

Peralatan dan bahan utama yang digunakan dalam percobaan di antaranya:

1. Kontak Inkubator, sebagai tempat melakukan pengambilan data yang terisolir. Kotak berukuran 2X1X1,5 meter.

2. Projector Stand, tempat pemegang dan pengatur posisi projector.

3. DLP projector, sebagai sumber sinar exposure dengan jenis Toshiba TDP-SC25 [11] dengan spesifikasi:1.800 lumens, resolution: SVGA - SVGA (800 x 600), Contrast Ratio : 2000:1; kemudian Infocus IN114A [12] dengan spesifikasi: 2700 lumens, resolution: XGA (1024 x 768),Contrast ratio: 4000:1.

4. Spin coater, sebagai alat meratakan cairan resist pada permukaan substrate/ $P C B$ dengan cara diputar.

5. Hot plate, sebagai alat pengering substrate.

6. Negative Photoresist, berfungsi membentuk lapisan pelindung bagian profil yang ingin dimunculkan. Jenis yang dipakai Aldrich negative photoresist kit.[10]

\section{HASIL DAN PEMBAHASAN}

Supaya mendapatkan hasil yang maksimal, pengambilan data menggunakan berdasarkan dari penelitian yang sama atau dari produsen alat yang digunakan. Karena data penelitian tentang visible light maskless photolithography tidak ditemukan maka sebagai data awal diambil dari produsen photoresist. Cairan resist yang digunakan adalah negative photoresist dari Aldrich, terdapat keteranggan: Substrate Preparation, 20-30 menit pada $120-130^{\circ} \mathrm{C}$; Photoresist Application, menggunakan sistem spin-coating(diputar) 500-1000 rpm; Prebake, 20 menit pada $82^{\circ} \mathrm{C}$; Photoresist Exposure, 1-10 detik minimum light source $10 \mathrm{~mW} / \mathrm{cm}^{2}$; Photoresist Develop, 10-60 detik; Postbake, 10 menit pada $120^{\circ} \mathrm{C}$. Setelah dilakukan beberapa percobaan menggunakan langkah dan parameter sesuai keterangan produsen resist, ternyata tidak berhasil. Analisa awal karena perbedaan sumber sinar exposure. Terdapat juga parameter yang tidak cocok seperti waktu prebake yang terlalu lama padahal substrate yang diproses berukuran kecil, sehingga kita pilih 
mempersingkat waktu prebake menjadi 2 menit, dan dilakukan setelah proses preparation (persiapan/ pembersihan) dan sebelum proses spin coating (pelapisan cairan resist dengan cara diputar). Alasan memindahkan proses prebake karena jika dilakukan setelah spin coating maka resist akan mengeras sebelum diexposure. Selanjutnya proses post bake juga kita percepat menjadi 3 menit dengan alasan jika dilakukan selama 10 menit terlalu lama karena substrate berukuran kecil cepat kering. Tetapi ada juga parameter yang dipakai seperti kecepatan spin coating yang digunakan yaitu pada kecepatan $2.000 \mathrm{rpm}$. Selanjutnya untuk mendapatkan hasil yang terbaik dilakukan beberapa variasi pengambilan data diantaranya:

\section{Waktu Exposure}

Pengambilan data pertama yaitu mencari waktu exposure terbaik dengan menggunakan proyektor $D L P$ Toshiba TDP-SC25 yang akan menyinari negative photoresist dibawahnya. Karena projektor memiliki titik fokus terdekat 2,5 meter maka dibutuhkan lensa pemfokus untuk mendekatkan jarak fokusnya. Dengan lensa pembesaran $3 \mathrm{X}$ didapat setingan jarak antara projector dan lensa $13 \mathrm{~cm}$ dan jarak lensa ke landasan (substrate) $14 \mathrm{~cm}$. Untuk lebih mudah melakukan pengamatan dan pengukuran dipilih substrate wafer silicon kemudian dilapisi negative photoresist. Warna yang digunakan Hitam (R:0 G:0 B:0) dan Putih (R:255 G:255 B:255), Waktu exposure diambil menurun mulai dari 60, 30, 15 dan 10 menit kemudian didevelop. Pada waktu exposure 60, 30 dan 15 menit bentuk profil tidak terlihat karena cairan resist sudah mengeras semua baik yang warna hitam maupun warna putih sehingga setelah didevelop resist tidak bisa hilang, kemudian pada 10 menit profil sudah terbentuk tapi pada bagian tepi profil masih kasar.

Dilanjutkan dengan pengambilan data exposure dari 1 menit sampai 10 menit, dengan waktu developing 5 menit. Dari hasil yang didapat waktu exposure 1, 2, 3 dan 4 menit resis yang sudah diexposure setelah didevelop hilang tidak membekas. Kemudian pada waktu exposure 5, 6 dan 7 menit resist membentuk profil sesuai model. Sedangkan waktu exposure 8, 9 dan 10 menit profil hasil terbentuk tetapi pada bagian tepi resis yang seharusnya hilang masih membekas karena waktu exposure yang berlebih.

Sehingga diambil keputusan waktu terbaik exposure menggunakan DLP projector Toshiba TDP-SC25 yaitu 5, 6 atau 7 menit.

\section{Variasi waktu Developing}

Developing adalah proses menghilangkan cairan resis yang tidak dibutuhkan setelah diexposure. Proses ini sangat penting karena berpengaruh terhadap kualitas profil yang dihasilkan. Untuk membandingkan hasil developing maka dipilih waktu exposure yang sama yaitu 5 menit. Variasi waktu dimulai dari 1 menit sampai 10 menit. Dari percobaan didapat waktu developing 1 dan 2 menit semua resist belum terdevelop, waktu 3 dan 4 profil sudah terbentuk tetapi pada bagian tepi menyisakan resist yang seharusnya hilang. Pada waktu develop 5 dan
6 menit bentuk profil sesuai model. Sedangkan pada waktu 7 sampai 10 menit seluruh resist terdevelop atau hilang.

Sehingga diambil waktu terbaik proses developing yaitu 5 atau 6 menit.

\section{Variasi Profil}

Variasi profil dibutuhkan untuk melihat hasil exposure apakah sesuai dengan model atau tidak. Setelah bentuk profil segi tiga dan persegi sudah dibuat selanjutnya dilakukan percobaan bentuk profil yang lebih rumit. Dipilih bentuk profil roda gigi berjumlah 12 buah dan resist hasil proses develop dapat dilihat pada gambar 4.

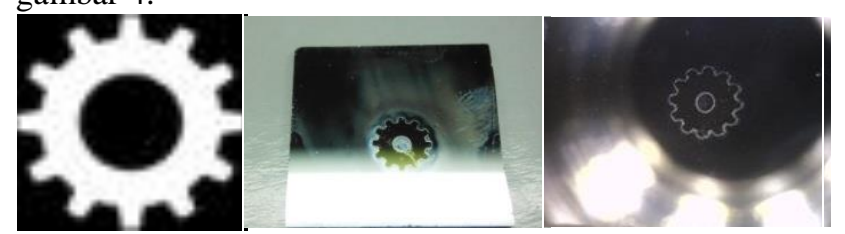

Gambar 4. Profil model roda gigi dan hasil developing

Setelah dilakukan pengamatan menggunakan microscope digital ternyata bentuk lingkarang hasil exposure tidak simetrik, bentuk lingkaran pada bagian tengah roda gigi menjadi oval.

Perbaikan yang dilakukan adalah dengan memiringkan lensa pemfokus yang berada di antara $D L P$ projector dan substrate sebesar $7^{0}$ seperti pada gambar 5 .

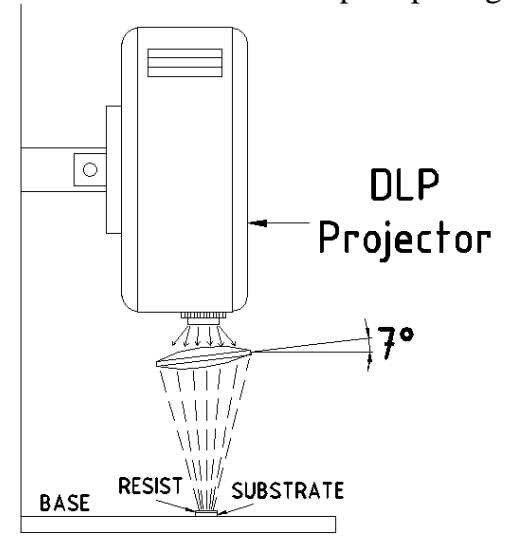

Gambar 5. Sudut lensa pemfokus

\section{Variasi Kombinasi Warna}

Berdasarkan penelitian sebelumnya yang dilakukan Dhanesh K.R dan kawan-kawan ada masalah pada proses maskless photolithography menggunakan DLP projector, yaitu pada bentuk profil model persegi pada sisi-sisinya tidak tajam. Setelah dilakukan percobaan ternyata benar masalah tersebut muncul pada saat membuat profil roda gigi kecil. Pada profil roda gigi yang dipancarkan melalui DLP projector berubah menjadi profil mirip lingkaran karena puncak roda gigi menjadi tidak jelas atau disebut "blur" seperti pada gambar 6. 


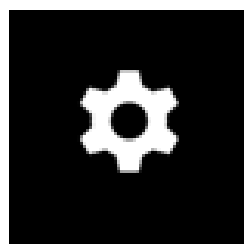

Profil pada laptop

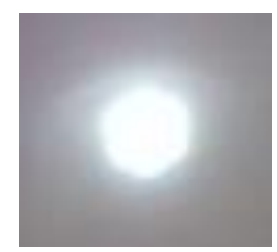

Profil projector
Gambar 6. Blur

Perbaikan dilakukan dengan mengatur posisi dan jarak antara projector lensa dan substrate dengan tujuan memperbaiki titik fokus tetapi tetap tidak berhasil. Pergantian bentuk profil juga dilakukan dengan merubah bentuk roda gigi menjadi bentuk persegi supaya lebih sederhana, tetapi pada profil persegi juga tetap terdapat blur. Selanjutnya dilakukan percobaan dengan mengganti kombinasi warna yang dipancarkan projector. Warna Hitam-Putih akan dirubah dengan warna tetap Hitam dikombinasikan dengan warna lain seperti pada gambar 7.

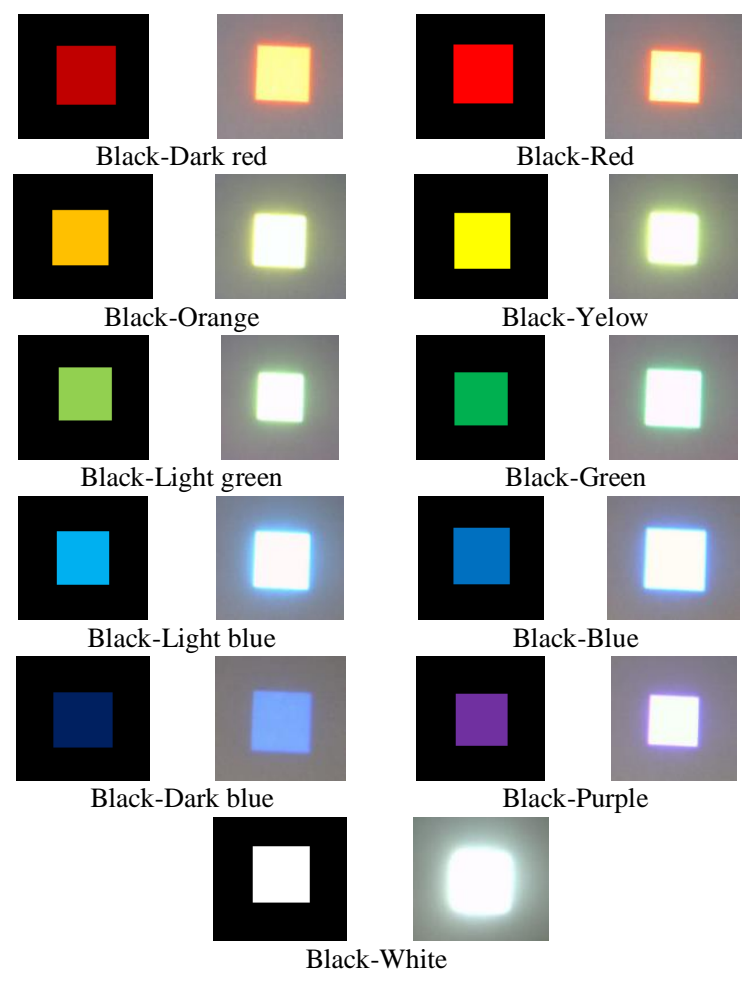

Gambar 7. Kombinasi warna dan profil dari projector

Dari profil yang keluar dapat dilihat dengan jelas warna kombinasi hitam dan putih paling tidak direkomendasikan karena bentuk persegi tidak memiliki sudut yang tajam.

Kemudian untuk meyakinkan dilakukan pengambilan data kombinasi warna diantaranya: Hitam-merah tua $(R=192, G=0, B=0)$; Hitam-Merah $(R=255, G=0, B=0$; Hitam-Orange $(R=255, \quad G=192, \quad B=0)$; Hitam-Kuning $(R=255, G=255, B=0)$; Hitam- hijau terang $(R=106$, $G=208, \quad B=80)$; Hitam-hijau $(R=0, \quad G=176, \quad B=80)$; Hitam-biru terang $(R=0, G=176, B=240)$; Hitam-Biru $(R=0, G=112, B=192)$; Hitam-biru tua $(R=0, G=32$, $B=96)$; Hitam-Ungu $(R=112, G=48, B=160)$. Kombinasi warna tadi akan dilakukan dengan pengaturan waktu exposure 5 menit dan waktu developing 5 menit. Hasil dari kombinasi warna tadi dapat dilihat pada tabel 1 .

Tabel 1. Hasil pengukuran kombinasi warna

\begin{tabular}{|c|c|c|c|c|}
\hline TEST & $\begin{array}{c}\text { KOMBINASI } \\
\text { HITAM DAN }\end{array}$ & $\begin{array}{c}\text { DEF. } \\
(\boldsymbol{\mu m})\end{array}$ & $\begin{array}{c}\text { STD.Err } \\
(\boldsymbol{\mu m})\end{array}$ & $\begin{array}{c}\text { Ra } \\
(\boldsymbol{\mu m})\end{array}$ \\
\hline 1 & Merah tua & gagal & gagal & Gagal \\
\hline 2 & Merah & gagal & gagal & Gagal \\
\hline 3 & Orange & gagal & gagal & Gagal \\
\hline 4 & Kuning & gagal & gagal & Gagal \\
\hline 5 & Hijau Terang & 83,9 & 27,2 & 0,45 \\
\hline 6 & Hijau & 50,8 & 21,8 & 1,14 \\
\hline 7 & Biru Terang & 13,7 & 6,9 & 0,02 \\
\hline 8 & Biru & 14,0 & 5,5 & 0,05 \\
\hline 9 & Biru Tua & 89.8 & 23,5 & 0,11 \\
\hline 10 & Ungu & 17,4 & 26,2 & 0,23 \\
\hline
\end{tabular}

Profil yang dihasilkan ternyata kombinasi HitamMerah tua, Hitam-Merah, Hitam-Orange dan HitamKuning dinyatakan gagal karena resis hasil exposure terdevelop atau hilang. Selanjutnya grafik perbandingan kombinasi warna yang berhasil dapat dilihat pada gambar 8 .

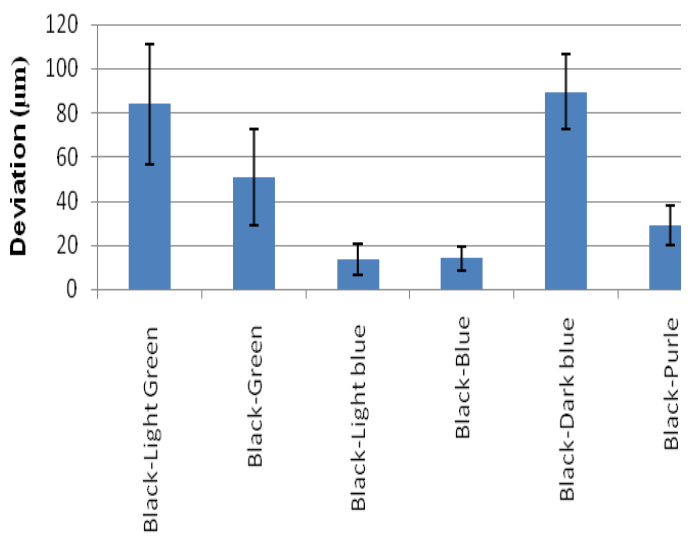

Gambar 8. Hasil kombinasi warna

Dari hasil data kombinasi warna maka diperoleh hasil terbaik pada kombinasi warna Hitam dan Biru terang (Black-Light Blue) dengan deviasi atau kekasaran tepi $13,7 \mu \mathrm{m}$.

\section{Variasi Jenis Projector}

Variasi jenis DLP projector dilakukan untuk memastikan bahwa proses maskless photolithograpy dapat dilakukan pada semua jenis DLP projector. DLP projector kedua dipilih Infocus IN114A [12].

Karena sudah didapat data hasil percobaan pada projector pertama sehingga pada percobaan projector kedua tidak akan dilakukan variasi kombinasi warna dipilih kombinasi warna Hitam dan Biru terang (BlackLight Blue), kecepatan spin coating $2.000 \mathrm{rpm}$, prebake 2 menit dan postbake 3 menit, tetapi variasi lainnya tetap dilakukan diantaranya: 


\section{a. Waktu Exposure}

Waktu exposure (penyinaran) dilakukan kembali karena DLP projector pertama dan kedua memiliki spesifikasi berbeda. Pada projector pertama DLP Toshiba TDP-SC25 dihasilkan data exposure seperti pada gambar 9, 10, 11 dan 12 .

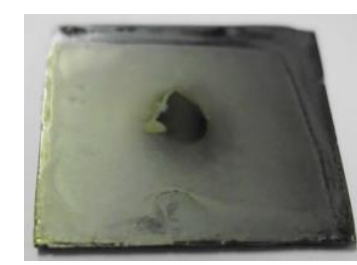

1 menit

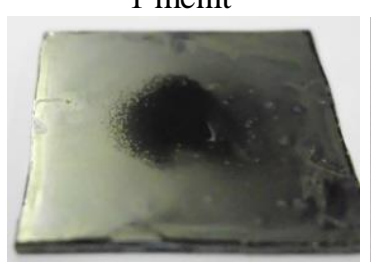

3 menit

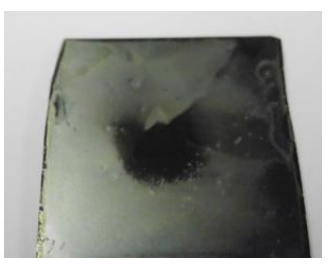

2 menit

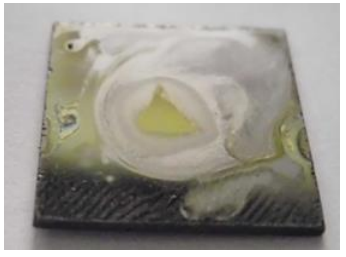

4 menit
Gambar 9. Hasil exposure DLP toshiba 1 - 4 menit

Gambar 9 adalah hasil profil segitiga yang diexposure diatas silicon dengan waktu penginaran 1 sampai 4 menit kemudian di develop. Dari gambar terlihat waktu 1 sampai 3 menit profil segitiga terkelupas oleh developer, pada waktu exposure 4 menit profil mulai terlihat tapi belum sempurna.

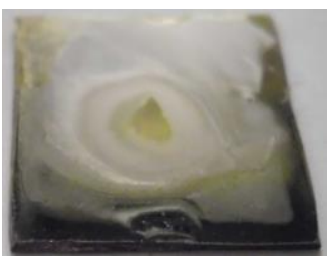

5 menit

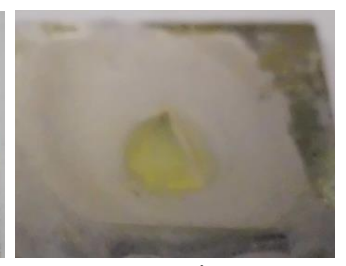

6 menit
Gambar 10. Hasil exposure DLP toshiba 5 - 6 menit

Pada gambar 10 adalah hasil exposure dengan waktu 5 dan 6 menit, terlihat bentuk profil segitiga tetapi masih ada resist yang terdevelop.

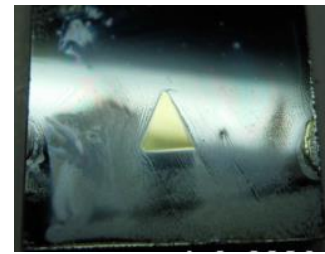

7 menit

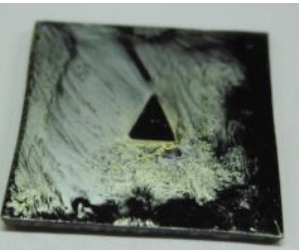

8 menit
Gambar 11. Hasil exposure DLP toshiba 7 - 8 menit

Gambar 11 adalah hasil exposure dengan waktu 7 dan 8 menit, terlihat bentuk profil sudah sesuai dengan model pada waktu 7 menit. Kemudian pada waktu 8 menit profil terbentuk tetapi resist bagian diluar profil tersisa.
9 menit

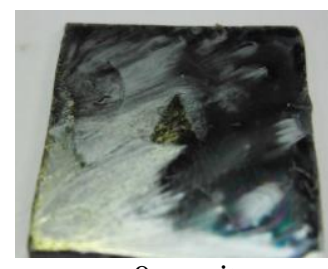

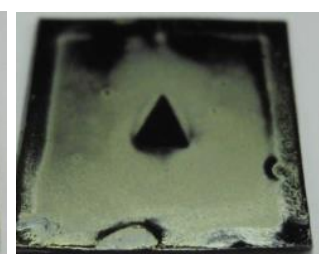

10 menit
Gambar 12. Hasil exposure DLP toshiba 9 - 10 menit

Gambar 12 adalah hasil exposure dengan waktu 9 dan 10 menit, pada kedua gambar terlihat profil terbetuk tetapi resist bagian luar ikut mengeras dan tidak hilang oleh proses developing.

Dari hasil pengambilan data disimpulkan waktu terbaik untuk proses exposure DLP projector Toshiba TDP-SC25 adalah 7 menit. Setelah dapat waktu terbaik selanjutnya dilakukan di atas $P C B$ dan sesuai dengan profil.

Kemudian dilakukan pengambilan data waktu exposure pada DLP projector kedua yaitu Infocus IN114A. Pada projector ini ditemukan data seperti pada gambar 13, 14, 15 dan 16.

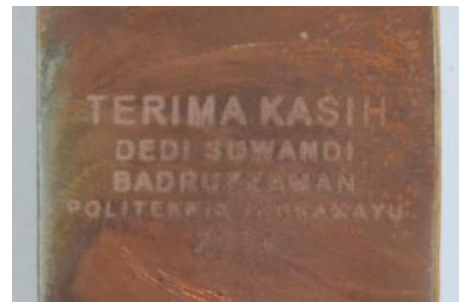

Gambar 13. Hasil exposure DLP Infocus 2 menit

Pengambilan data pada DLP projector kedua dimulai dari 2 menit karena mengacu data percobaan pertama 4 menit waktu exposure profil baru terbentuk. Percobaan kedua tidak lagi diatas silicon tetapi dilakukan di papan $P C B$ selanjutnya lakukan proses developing dan eching untuk melihat hasilnya. Ternyata pada projector kedua dengan waktu 2 menit profil sudah terbentuk seperti pada gamabar 13, tetapi beberapa profil huruf belum terbentuk karena resist yang terexposure belum mengeras sehingga pada waktu developing resist tersebut terkelupas.

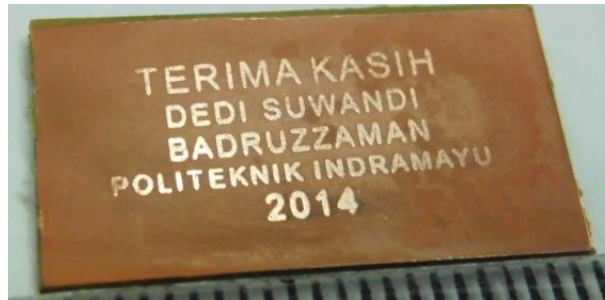

Gambar 14. Hasil exposure DLP Infocus 3 menit 
Pada gambar 14 adalah hasil exposure 3 menit, terlihat profil huruf sudah terbentuk sesuai dengan model.

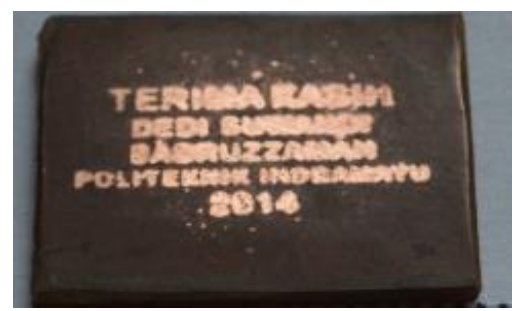

Gambar 15. Hasil exposure DLP Infocus 4 menit

Gambar 15 adalah hasil exposure 4 menit, profil huruf terbentuk semua tetapi pada bagian sisi huruf tidak halus. Kemudian pada sisi lain juga terdapat bercak ini disebabkan karena resist selain pada profil huruf sudah mengeras sehingga pada waktu dilakukan proses eching lapisan tembaga yang seharusnya terkikis terlindungi oleh resist yang tidak diinginkan tadi.

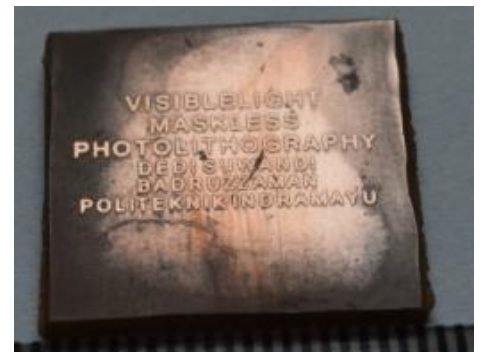

Gambar 16. Hasil exposure DLP Infocus 5 menit

Selanjutnya dilakukan proses exposure dengan waktu 5 menit dengan projector kedua. Pada gambar 16 profil huruf terbentuk tetapi resist yang tertinggal setelah proses developing semakin banyak. Kejadian ini juga dialami pada saat percobaan dengan projector pertama ketika waktu exposure melewati waktu terbaik.

Dari pengambilan data waktu terbaik exposure untuk DLP projector Infocus IN114A adalah 3 menit. Selanjutnya projector ini yang akan digunakan pada proses selanjutnya karena lebih cepat dalam pengambilan data.

\section{b. Waktu Developing}

Pencarian waktu developing terbaik juga dilakukan karena akan mempengaruhi terkelupasnya cairan resist pada $P C B$. Tetapi hasil proses developing tidak dapat dilihat perbedaannya karena warna cairan resist dan tembaga hampir sama seperti pada gambar 17.

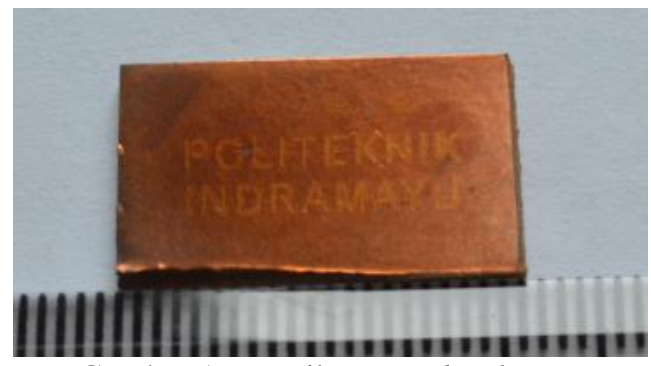

Gambar 17. Hasil proses developing
Sehingga untuk melihat perbedaan hasil proses developing terhadap waktu dilakukan proses eching pada masing-masing waktu seperti gambar 18, 19, 20 dan 21.

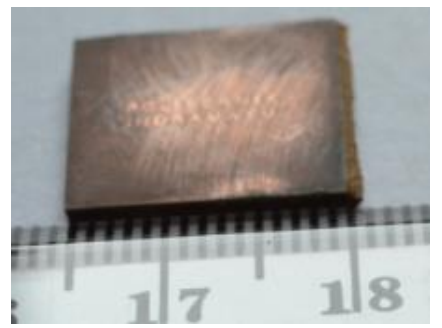

Gambar 18. Hasil developing 2 menit

Hasil developing 1 menit tidak terbentuk karena waktu yang sangat singkat, pada waktu developing 2 menit profil sudah terlihat tetapi karena resist masih banyak yang belum terkelupas oleh developer maka menutupi sebagian profil seperti pada gambar 18 .

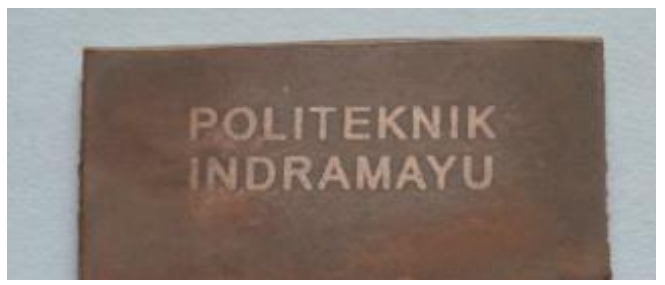

Gambar 19. Hasil developing 3 menit

Pada gambar 19 adalah hasil developing dengan waktu 3 menit, terlihat bentuk profil sudah sesuai model. Kemudian pada waktu 4 menit juga menghasilkan bentuk hasil yang hampir sama jika dilihat dengan mata.

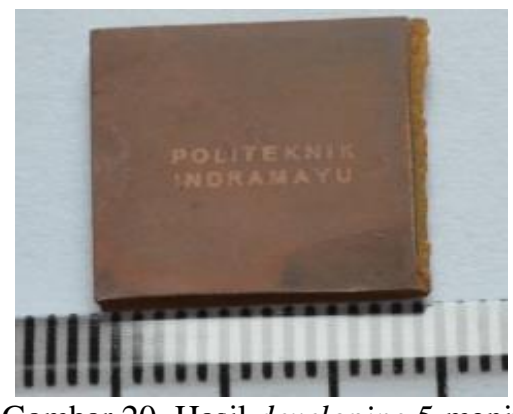

Gambar 20. Hasil developing 5 menit

Pada gambar 20 adalah hasil proses developing dengan waktu 5 menit, terlihat profil mulai terkikis karena resist yang seharusnya tertinggal terangkat karena lamanya waktu developing. Hasil yang hampir sama juga pada waktu developing 6 menit.

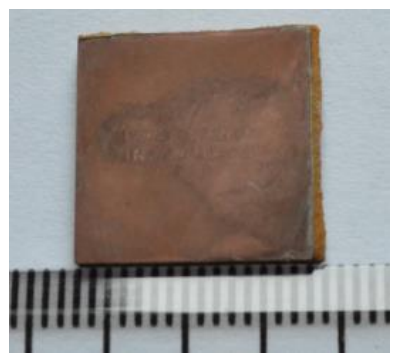

Gambar 21. Hasil developing 7 menit 
Ketika waktu developing ditambah menjadi 7 menit seperti gambar 21 hampir semua profil huruf tidak terbentuk karena resist sudah terangkat oleh cairan developer semua.

Sehingga dari pengambilan data variasi waktu developing terbaik adalah $3-4$ menit.

Dengan data hasil percobaan kedua pojector maka perbandingan parameter terbaik kedua jenis DLP projector dapat dilihat pada tabel 2 berikut.

Tabel 2. Parameter maskless photolithography DLP

projector

\begin{tabular}{|l|c|c|}
\hline $\begin{array}{c}\text { Jenis DLP } \\
\text { Projector }\end{array}$ & $\begin{array}{c}\text { Toshiba TDP- } \\
\text { SC25 }\end{array}$ & $\begin{array}{c}\text { Infocus } \\
\text { IN114A }\end{array}$ \\
\hline Prebake & 2 menit & 2 menit \\
\hline Spin coating & $2.000 \mathrm{rpm}$ & $2.000 \mathrm{rpm}$ \\
\hline Exposure & 5 menit & 3 menit \\
\hline Developing & 5 menit & 5 menit \\
\hline Postbake & 3 menit & 3 menit \\
\hline Eching & 3 menit & 3 menit \\
\hline
\end{tabular}

Dari tabel 2 diketahui jenis DLP projector Infocus IN114A lebih baik dari jenis Toshiba TDP-SC25, dilihat dari waktu exposure lebih cepat. Sehingga untuk proses selanjutnya dipilih projector jenis Infocus IN114A untuk mendapatkan hasil yang lebih baik.

\section{Variasi Waktu Proses Eching}

Proses eching dilakukan setelah proses maskless photolithography selasai tujuannya adalah untuk mengikis bahan yang tidak dibutuhkan. Karena tujuan awal penelitian ini adalah menemukan metode baru fabrikasi membentuk jalur listrik pada $P C B$, maka parameter terbaik proses maskless photolithography yang sudah didapat akan diaplikasikan pada $P C B$. Karena $P C B$ memiliki lapisan tembaga pada salah satu bagian permukaannya sehingga cairan echant yang dapat mengikis salah satunya Ferri Chloride $\left(\mathrm{FeCl}_{3}\right)$.

Selanjutnya $P C B$ hasil proses visible light maskless photolithography kedua jenis DLP disiapkan untuk proses eching, waktu eching dipilih dari 1 sampai 10 menit dengan hasil sebagai berikut: 1 sampai 2 menit tembaga belum terkikis; 3 sampai 4 menit tembaga sudah terkikis sebagian; 5 sampai 6 menit tembaga terkikis dan bagian yang terlindungi resist masih terbentuk; 7 sampai 10 menit tembaga yang tidak terlindungi resist terkikis tetapi bagian yang terlindungi resist juga ikut terkikis. Hasil proses eching dapat dilihat pada gambar 22.

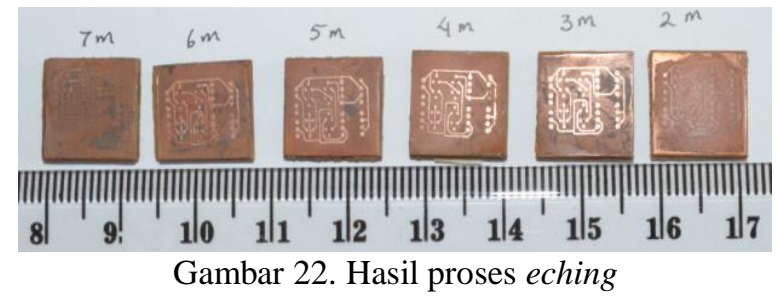

Sehingga waktu terbaik proses eching $P C B$ produk hasil maskless photolithography yaitu 5 atau 6 menit.

\section{Aplikasi Pada $P C B$}

Setelah mendapatkan hasil parameter terbaik tahapan maskless photolithography selanjutnya diaplikasikan ke $P C B$ untuk mengetahui produk akhir dari proses tersebut. Dari profil yang berhasil dibuat dengan metode Visible Light Maskless Photolithography dengan cairan echant ferric chloride diantaranya, huruf dan alur sirkuit listrik.

\section{a. Huruf}

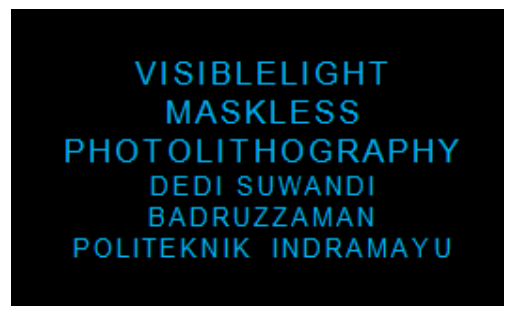

Gambar 23. Profil model huruf

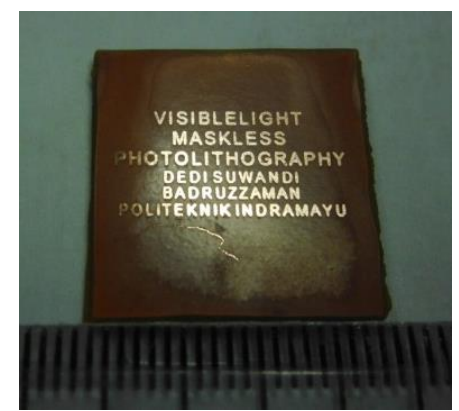

Gambar 24. Hasil eching model huruf

Pada pembuatan profil huruf model awal dapat dilihat pada gambar 23 dengan menggunakan jenis font Arial size 14 untuk 3 baris pertama dan size 11 pada 3 baris terakhir. Profil dibuat pada M.S. PowerPoint dengan latar belakang hitam dan huruf biru terang, kemudian hasil produk setelah dilakukan proses eching dapat dilihat pada gambar 24.

\section{b. Alur Microcontroller}

Pada percobaan kedua dipilih profil yang rumit yaitu profil model microcontroller seperti gambar 25, profil ini dibuat menggunakan software AutoCAD supaya dapat membuat profil garis, kotak dan lingkaran yang sesuai keinginan. Pada profil ini juga dilakukan kombinasi warna latar hitam dan profil biru terang, selanjutnya profil dimasukan ke M.S. PowerPoint untuk dipancarkan melalui DLP projector. Profil dibuat dengan panjang 9 $\mathrm{cm}$ dan tinggi $7 \mathrm{~cm}$, kemudian hasil produk setelah dilakukan proses eching dapat dilihat pada gambar 26 .

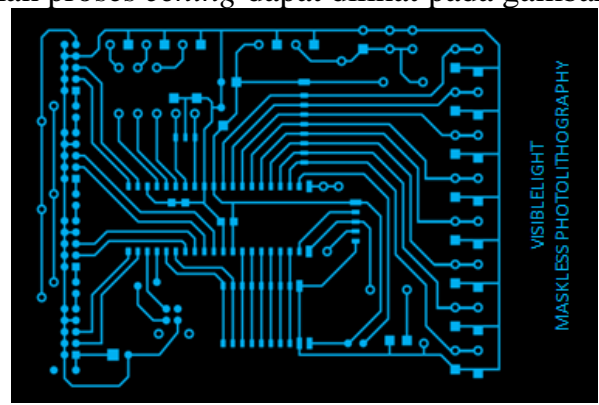

Gambar 25. Profil Model microcontoller 


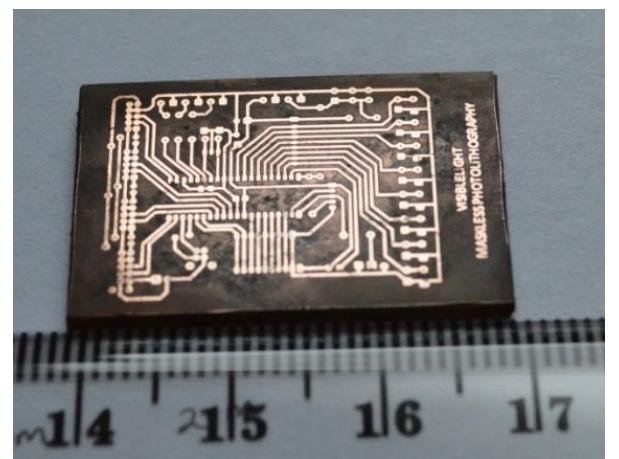

Gambar 26. Hasil eching model microocontroller

\section{Pengukuran Hasil Produk PCB}

Setelah kedua produk proses visible light maskless photolithography berhasil dibuat selanjutnya dilakukan pengukuran menggunakan Scanning electron Microscope (SEM) untuk melihat ukuran yang lebih teliti. Hasil pengukuran dapat dilihat pada gambar 27, 28 dan 29.

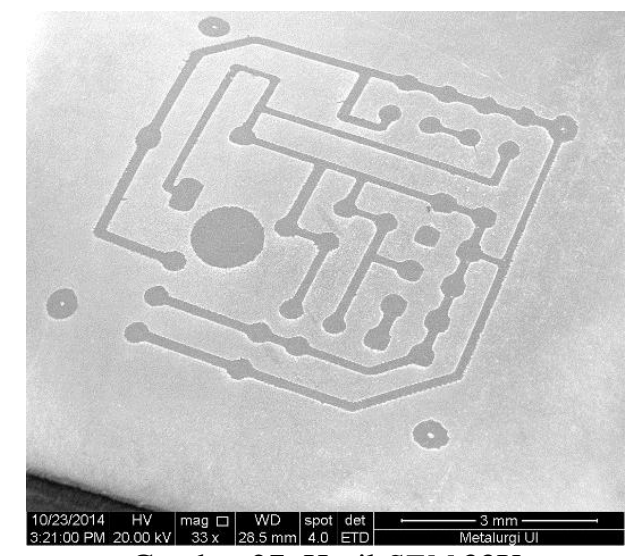

Gambar 27. Hasil SEM 33X

Pada gambar 27 dilakukan pembesaran 33 kali, terlihat seluruh jalur listrik pada $P C B$.

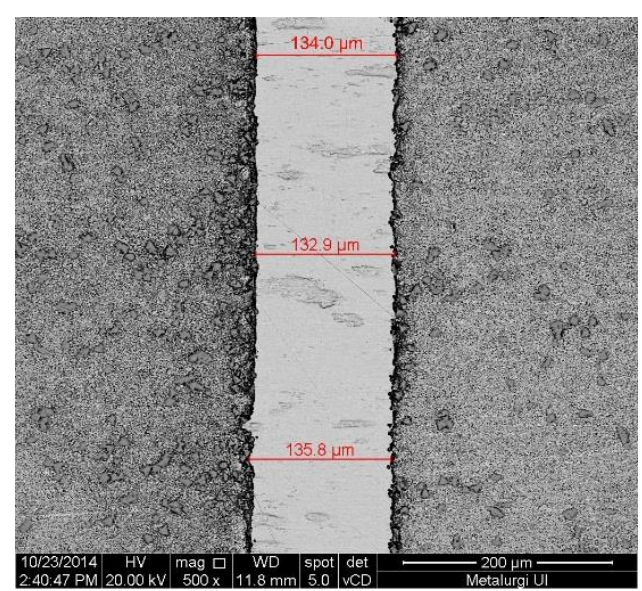

Gambar 28. Hasil SEM 500X

Gambar 28 adalah hasil pengukuran dengan pembesaran 500 kali, lebar jalur listrik yang dibuat adalah $132 \mu \mathrm{m}$.

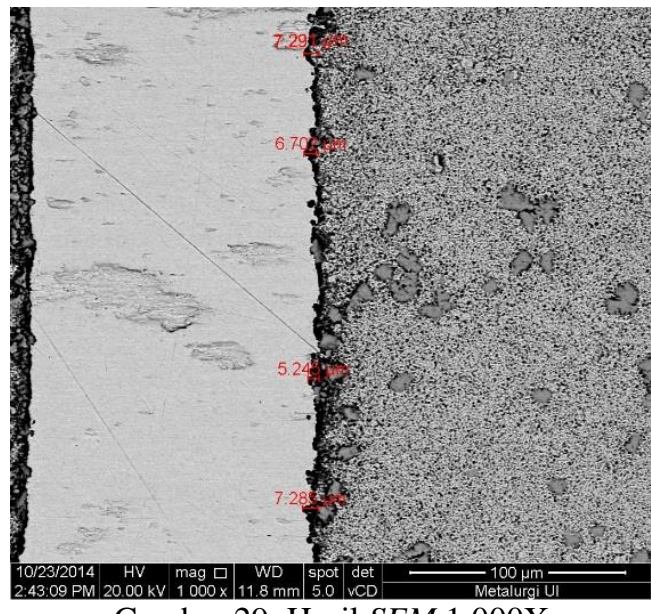

Gambar 29. Hasil SEM 1.000X

Seperti terlihat pada gambar 29 pengukuran dilakukan dengan pembesaran 1.000 kali tujuannya adalah mengukur deviasi atau kerataan tepi jalur listrik pada $P C B$. Dari pengukuran dihasilkan deviasi dengan jarak rata-rata $6,6 \mu \mathrm{m}$.

\section{PENUTUP \\ Kesimpulan}

Setelah dilakukan percobaan tentang proses fabrikasi PCB menggunakan metode Visibleligth Maskless Photolitography, diambil kesimpulan diantaranya:

1. Metode visible light maskless photolithography menggunakan DLP Projector berhasil dilakukan dengan jenis Toshiba TDP-SC25 (1800 lumens, Contrast ratio $=2000: 1)$ dan Infocus IN114A (2700 lumens, Contrast ratio $=4000: 1$ ).

2. Parameter terbaik visible light maskless photolithography didapatkan dari DLP Projector jenis Infocus IN114A dengan parameter posisi lensa pemfokus pembesaran $3 \mathrm{X}$ berjarak $3 \mathrm{~cm}$ dibawah $D L P$ projektor dan $14 \mathrm{~cm}$ diatas material uji papan PCB, menggunakan kombinasi warna hitam dan biru terang ( $R=0, G=176, B=240)$ dengan waktu prebake 2 menit, spin $2000 \mathrm{rpm}$, exposure 3 menit, Develop 5 menit, Postbake 5 menit dan Eching 5 menit.

3. Profil yang berhasil dibuat diantaranya: garis, huruf, alur listrik, dan bentuk microcontroller. Profil garis terkecil yang dapat dibuat yaitu $\mu \mathrm{m} 132 \mu \mathrm{m}$ dan memiliki kekasaran tepi (deviasi) 6,6 $\mu \mathrm{m}$.

\section{Saran}

Beberapa saran bagi pihak yang ingin menggunakan metode Visibleligth Maskless Photolitography, diantaranya:

1. Gunakan selalu alat pelindung diri terutama kaca mata anti $U V$ dan sarung tangan pada saat pengambilan data.

2. Jika jenis DLP Pjojector yang digunakan berbeda dari kedua jenis projector yang sudah diuji, maka perlu mencari parameter terbaik projecor tersebut seperti mencari waktu exposure, waktu developing dan waktu eching. 


\section{DAFTAR PUSTAKA}

[1] Triano, A., Collins, S., "Development of a PCB printer using an ultraviolet laser diode", Systems, Applications and Technology Conference (LISAT), IEEE Long Island, 2013, pp:1-6.

[2] Aos Alwaidh, Laser processing of rigid andflexible PCBs, Optics and Lasers in Engineering (58), 2014, pp 109-113.

[3] Arturo Moreno-B́aez, Processing Gerber files for manufacturing printed circuit boards, Procedia Engineering, Volume 35, 2012, Pages 240-244.

[4] Y. Hirai, Y. Inamoto, K. Sugano, T. Tsuchiya, O. Tabata, "Moving-mask UV Lithography for 3-dimensional Positive-And Negative-Tone Thick Photoresist Micromanufacturing", Solid-State Sensors, Actuators and Microsystems Conference Transducers International, Lyon,2007 pp: $545-548$.

[5] A. Bertsch, H. Lorenz, P. Renaud, 3D microfabrication by combining microstereolithography and thick resist UV lithography, International Journal of Sensors and Actuators 73, 1998, p: 14-23.

[6] S.M.P. Kalaiselvi, Tan, T.L. ; Talebitaher, A. ; Lee, P, "Neon Soft X-Ray Lithography source Base On Low Energy Fast Miniature Plama Focus Device" Plasma Sciences (ICOPS) held with IEEE International Conference on High-Power Particle Beams (BEAMS), Washington DC, 2014, pp:1-6

[7] W. Ehrfeld, A. Schmidt, 1998, Recent developments in deep X-ray lithography, J. Vac. Sci. Technol. B 16 Mechanical Systems, Oiso, Japan, pp. 81-85.

[8] Dhanesh Kattipparambil Rajan, JukkaPekka Raunio, Markus Tapani Karjalainen, Tomi Ryynänen, Jukka Lekkala, 2013 "Novel method for intensity correction using a simple maskless lithography device, Sensors and Actuators A 194, 2013, p:40- 46.

[9] Wolfwikis(2015,Sep,16)http://wikis.lib.ncsu. edu/index.php/Soft_Lithography

[10] Sigmaaldrich (2015, Sep, 16) http://www.sigmaaldrich.com/technicaldocuments/protocols/materialsscience/negative-photoresist.html

[11] Toshiba (2015, Sep, 10) http://www.cnet.com/products/toshiba-tdpsc25-dlp-projector-series/specs/

[12] ] Infocus (2015, Sep, 10) http://www.infocus.com/projectors/IN114\#sp ecs 